\title{
APPRAISING FABRICATION AND WELDING STUDENTS' EMPLOYABILITY SKILLS IN OGUN STATE TECHNICAL COLLEGES
}

\author{
Olakotan Olusegun Olawale ${ }^{1}$; Lemo Olusiji Olaseni ${ }^{2}$ \\ ${ }^{1}$ Department of Vocational and Technical Education, Ekiti State University, Ado-Ekiti, Nigeria \\ ${ }^{2}$ Department of Technical Education, Tai Solarin University of Education, Ijagun, Nigeria
}

\author{
olusegunolakotan@yahoo.com ${ }^{1}$; rossandlemo@yahoo.co.uk ${ }^{2}$
}

First draft received: 9 July 2018 Date Accepted: 31 Dec 2018 Final proof received: 9 Feb 2019

\begin{tabular}{|c|}
\hline Abstract \\
\hline $\begin{array}{l}\text { This study appraised fabrication and welding students' employability skills in Ogun State technical } \\
\text { colleges. Two research questions were raised in relation to the focus of the study. A structured } \\
\text { Questionnaire containing } 15 \text { items was developed and used for data collection. The questionnaire was } \\
\text { validated by } 3 \text { experts and tested for reliability using Cronbach Alpha Coefficient at } 0.96 \text {. The questionnaire } \\
\text { was used for collecting data from } 57 \text { respondents made by fabrication and welding industrial-based } \\
\text { supervisors in Ogun State. The data collected were analysed using descriptive statistics of mean and } \\
\text { standard deviation to answer the research questions raised in the study. The study affirmed that fabrication } \\
\text { and welding students in Ogun State technical colleges possessed sheet metalwork skills and gas welding } \\
\text { skills. The study recommended among others that adequate supervision and monitoring of Technical and } \\
\text { Vocational Education and Training (TVET) institution's students on industrial attachment should be } \\
\text { ensured by TVET institution's administrators and that industrial-based supervisors should be objective in } \\
\text { discharging their duties during students' industrial attachment period. }\end{array}$ \\
\hline Keywords: Employability skills; technical colleges; fabrication and welding \\
\hline 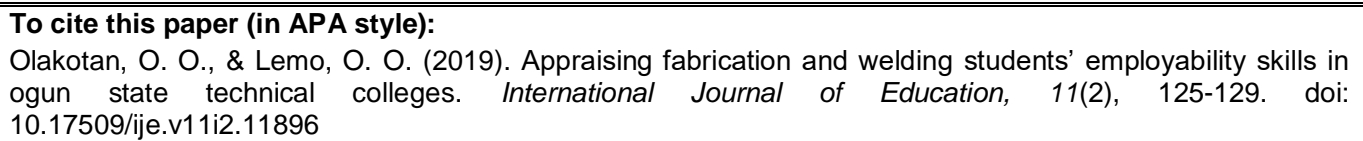 \\
\hline
\end{tabular}

\section{INTRODUCTION}

Employability skills development has been a major discourse in literature over the years. This is because it constitutes a vital ingredient in the development of the workforce and the development of a nation at large. Employers of labour often tilt towards graduates who possess requisite employability skills during different stages of interview for employment. This is due to the fact that the cost of training and retraining a graduate when employed seems to have escalated beyond normal, and thus industries could no longer afford it. Hence, the need for recruitment of graduates who possess the wherewithal to function effectively in the world of work becomes apparent.

Functionality in the world of work requires ability to demonstrate overtly employability skills that have overtime been acquired while in the training institution. This shows how vital it is for graduates across all levels of Technical and Vocational Education and Training (TVET) to be well equipped and possess the needed employability skills in the world of work. Employability skills according to Olakotan (2015) refers to those skills possessed by an individual which make him/her fit into the world of work. It refers to those basic skills necessary for getting, keeping, and doing well on job.
They are sometimes referred to as generic skills, capabilities, enabling skills, or key competencies.

Employability skills according to Science, Technology, Engineering and Mathematics Network (STEMNET, 2014) refer to transferable skills needed by an individual to make them employable. Along with good technical understanding and subject knowledge, employers often outline a set of skills that they want from an employee. In the views of Muhammad, Soetyono and Sunardi (2017), employability skills refer to the ability of an individual and the ease at which such individual survives and succeeds at work.

From the foregoing, employability skills refer to skills, knowledge, and attitude needed both to get a job and to do well in that job, which in turn will imply positive outcomes both for an individual and for his or her employing organization. Employability skills are set of skills, knowledge and attribute that likely make individual to gain, maintain, and excel in employment; obtain new employment; move between roles within the same organization and to get promotion (Rasul, Ismail, Ismail, Rajuddin, \& Rauf, 2010).

A number of studies in the Nigerian context have revealed the level of employability skills development among TVET institutions graduates. Olakotan (2015) 
assessed employability skills possessed by prospective graduates of technical colleges in mechanical engineering craft practice in Lagos State. The study found that employability skills possessed by technical college students are inadequate and thus could not secure a place in work places. Also, lack of adequate machines, tools, non-availability of workshops and lack of competent teachers hinder the acquisition of employability skills. The study also found out that inadequate infrastructural facilities and well equipped workshops do not promote the acquisition of manipulative and employability skills.

Idris and Rajuddin (2012) investigated the level of importance and competencies of employability skills among the final year TVET students in Nigeria. The findings indicated the need for TVET institutions in Nigeria to focus and equip the students with employability skills. In addition, some studies in Zimbabwe, Malawi and Tanzania have identified inadequate learning facilities; absence of industrial synergies and ineffective curricula among others as constituents of lack of employability skills in TVET institutions (Lemo \& Olakotan, 2016; Woyo, 2013; Anangisye, 2008). Also, few studies in Bangladesh and Ghana attributed lack of employability skills among TVET graduates to the absence of linkages between training institutions and the world of work (Dasmani, 2011; Islam \& Mia, 2007).

Some studies in Malaysia revealed that school graduates are not well prepared for the world of work, as there exists a gap between the skills acquired in schools and the one needed in the world of work (Rasul, Rauf \& Mansor, 2013). Similarly, Hanapi, Nordin, and Rus (2014) noted that lack of employability skills remain one of the greatest challenges facing a large number of Malaysian graduates. In another study conducted in India, it was discovered that half of Indian graduates lack requisite employability skills needed by industries (Mishra, 2014).

Since different studies reviewed did not include fabrication and welding, their various findings could not be generalized. Therefore, it is on the nongeneralization of other studies that this study appraised fabrication and welding students' employability skills in Ogun State technical colleges.

\section{THE CONTEXT OF THIS STUDY}

Technical colleges aimed at preparing students for acquisition of relevant knowledge and applied skills in different occupations at the craftsman level. This is geared towards making craftsmen responsive to self and the world of work at large. Similarly, the goal of education at the technical college according to Ekpenyong (2011) is to provide students with sound education that would enhance development of appropriate, social, mental and physical competencies. In emphasizing the importance of technical colleges, the Federal Government of Nigeria (FGN, 2013) relayed that trainees completing education at this level may either secure employment at the end of the whole course or after completing one or more modules of employable skill. This, according to FGN (2013), will enable trainees to set up their own business and become self-employed and also be able to employ others upon acquiring saleable skills in fabrication and welding.

Fabrication and welding at the technical college level is expected to equip students to a large extent with skills and knowledge in fabrication and welding works. Globally, countries of the world have different skills standard set for their citizenry. This is why Muhammad, Soetyono, and Sunardi (2017) cited Article 35 of the Republic of Indonesia Education Law ascertaining attitudes, knowledge, and skills as competencies expected to be displayed by graduates in accordance with agreed national standards. Yisa and Olakotan (2017) noted that fabrication and welding as one of the trades offered in the nation's technical college laid emphasis on acquisition of requisite skills for selfreliance and employment in the world of work. It must be noted that students are enrolled into fabrication and welding trade from Year I for a full time 3 year course. Hence, there are Year I, II, and III fabrication and welding students at different times. These students are usually posted to related industries at the completion of relevant modules for industrial attachment. At the level of industrial attachment, fabrication and welding students are supervised, guided and further trained by industrial-based supervisors who are rooted in the art of fabrication and welding. The essence of the industrialbased supervisors is to monitor and record the progress of the students in their care. This is done to ensure that fabrication and welding students have adequate industrial exposure during the industrial attachment period and are made to build on the skills acquired in their respective institutions.

The aim of fabrication and welding as highlighted by the Federal Government of Nigeria (2007) is to produce skilled craftsmen with good knowledge of the application of the equipment, materials, techniques and safety practices in fabrication and welding of metal projects. The National Board for Technical Education (NBTE, 2008) also stated that graduates of fabrication and welding should be able to carry out gas welding and cutting jobs on all types of metals, produce simple finished structural steel work projects with safety, use relevant equipment and techniques, apply protective wetting against corrosion on finished metal projects and market finished metal projects. However, NBTE (2008) emphasized sheet metalwork, gas welding and cutting, metal arc welding and structural steel work as areas where students are to be equipped and prepared for the world of work. This study therefore dwelt on sheet metalwork and gas welding areas to ascertain whether fabrication and welding students possess the needed employability skills necessary for employment and selfreliance in these areas.

Therefore, students who have acquired requisite skills in sheet metalwork and gas welding may be said to have acquired skills as welders and fabricators only at the craftsmen level. Welders are required to make, join and repair the metal parts for a massive range of 
machinery, equipment and structures while Fabricators are involved in the creation and repair of light or heavy metals. These, however, reveal that there are employment opportunities for students who possess employability skills as welders and fabricators in both sheet metalwork and gas welding.

Also, the choice of Ogun State as a destination for the study stemmed from the fact that the state has a good number of manufacturing industries that require the services of welders and fabricators at the craftsmen level. In the same vein, Ogun State proximity to Lagos State paves ways for high economic activity in the state. Hence, this study becomes significant.

Earlier studies carried out on employability skills in TVET institutions in Nigeria revealed that graduates from these institutions lack the needed employability skills for entry into the world of work. This study however delved into fabrication and welding trade in order to substantiate the claims of the previous studies done outside fabrication and welding but in TVET institutions. This was to ensure that, as it were for other trades in TVET institutions so it is, for fabrication and welding. Hence, this study appraised fabrication and welding students' employability skills in technical colleges in Ogun State.

This study appraised fabrication and welding students' employability skills in technical colleges in Ogun State. Specifically, the study aimed to determine: 1) Sheet metalwork skills possessed by fabrication and welding students; and 2) Gas welding skills possessed by fabrication and welding students.

\section{METHOD}

This study adopted a descriptive survey research design. Accordingly, Gall, Gall and Borg (2007) noted that a survey is a method of data collection using questionnaire or interviews to collect data from a sample that has been selected to represent a population to which the findings of the data analysis can be generalized. The design was considered suitable for the study since it sought the opinions of fabrication and welding industrial-based supervisors and no variable was manipulated.

The population of this study was all the fabrication and welding industrial-based supervisors in Ogun State. Purposive sampling technique was used for selecting the two technical colleges offering fabrication and welding in Ogun State. Also, 57 fabrication and welding industrial-based supervisors were purposively selected.

Appraising Fabrication and Welding Students' Employability Skills Questionnaire (AFWSEQ) containing 15 items was developed from NBTE curriculum which had initially been validated by NBTE curriculum experts and used for the study. The scaling response for the instrument was based on a 4 point Likert Scale ratings viz: Highly Possessed (HP) - 4, Possessed $(P)-3$, Rarely Possessed (RP) -2 and Not Possessed (NP)-1. The instrument was later validated by three industrial technical education experts and tested to obtain 0.96 reliability coefficient using Cronbach Alpha coefficient method. The instrument was personally administered on the respondents by the researcher. Due to adequate monitoring and guidance of the instrument, $100 \%$ return rate was achieved. The data collected were statistically analyzed using descriptive statistics of means and standard deviation as appropriate. A mean of 2.50 and above was considered positive, while a mean rating of less than 2.50 was regarded as negative.

\section{RESULTS}

The sheet metalwork skills possessed by fabrication and welding students

The results of survey on fabrication and welding students' sheet metalwork skills are provided in Table 1 below.

Table 1: Mean responses of respondents on sheet metalwork skills possessed by fabrication and welding students

\begin{tabular}{lllll}
\hline $\mathbf{S} / \mathbf{N}$ & \multicolumn{1}{c}{ Item Statements } & X & S.D & Remarks \\
\hline & & & & \\
\hline 1 & Mark out and form projects in sheet metal work & 3.61 & 0.60 & Agree \\
\hline 2 & Solder and braze various sheet metal project with maximum safety & 3.44 & 0.63 & Agree \\
\hline 3 & Solder and braze various sheet metal project with maximum safety & 3.27 & 0.51 & Agree \\
\hline 4 & Produce finished sheet metal projects involving various processes & 3.29 & 0.49 & Agree \\
\hline 5 & Draw templates for production of sheet metal projects & 3.45 & 0.50 & Agree \\
\hline 6 & Develop templates for production of sheet metal projects & 3.53 & 0.55 & Agree \\
\hline 7 & Produce templates for production of sheet metal projects & 3.34 & 0.66 & Agree \\
\hline
\end{tabular}

The data presented in table 1 revealed that all the 7 items (items 1-7) had a mean range of 3.27 to 3.61 . This indicated that the respondents agreed on all the 7 items on the sheet metalwork skills possessed by fabrication and welding students because their means were above the cut-off point of 2.50 . The standard deviation of the items also ranged from 0.49 to 0.66 . This showed that the respondents were close to one another in their responses. 


\section{The gas welding skills possessed by fabrication and welding students}

Table 2: Mean responses of respondents on welding skills possessed by fabrication and welding students

\begin{tabular}{lllll}
\hline S/N & \multicolumn{1}{c}{ Item Statements } & X & S.D & Remarks \\
\hline & & & & \\
9 & Apply general safety precaution & 3.29 & 0.76 & Agree \\
10 & Weld together different types of ferrous metals & 3.34 & 0.73 & Agree \\
11 & Weld together different types of non-ferrous metals & 3.18 & 0.68 & Agree \\
12 & Build up worn shaft or surfaces & 3.49 & 0.65 & Agree \\
13 & Apply fuel gas cutting process in cutting metals to given specification & 3.50 & 0.66 & Agree \\
14 & Identify various welding defects & 3.18 & 0.68 & Agree \\
15 & Rectify various welding defects & 3.05 & 0.74 & Agree \\
& & 3.27 & 0.62 & Agree
\end{tabular}

The data presented in table 2 revealed that all the 8 items (items 8-15) had a mean range of 3.18 to 3.50 . This indicated that the respondents agreed on all the 8 items on the gas welding skills possessed by fabrication and welding students because their means were above the cut-off point of 2.50. The standard deviation of the items also ranged from 0.62 to 0.76 . This showed that the respondents were close to one another in their responses.

\section{DISCUSSION}

It has often been said that students acquire functional skills when their learning environments are replica of where students will subsequently work. The findings of this study as shown in Table 1 revealed the sheet metalwork skills possessed by fabrication and welding students. The findings of this study are in consonance with the submissions of NBTE (2008). This was evident in the statement of NBTE (2008) that graduates of fabrication and welding should be able to carry out gas welding and cutting jobs on all types of metals, produce simple finished structural steel work projects with safety, use relevant equipment and techniques, apply protective wetting against corrosion on finished metal projects and market finished metal projects. Unlike the study of Rasul, Rauf and Mansor (2013) which indicated that school graduates are not well prepared for the world of work as there exists a gap between the skills acquired in schools and that needed in the world of work. This study however as revealed in Table 1 showed that fabrication and welding students acquired and demonstrated sheet metalwork skills correctly as observed by industrial-based supervisors who through years of industrial practice have the wherewithal to assess acquisition of sheet metalwork skills as possessed by the trainees.

In research question 2, the findings of the study revealed gas welding skills possessed by fabrication and welding students. The findings of the study were corroborated by NBTE (2008) who emphasized sheet metalwork, gas welding and cutting, metal arc welding and structural steel work as areas where students are to be equipped and prepared for the world of work. The findings of this study also deviated completely from the previous studies carried out by Mishra (2014) who noted that half of Indian graduates lacked requisite employability skills needed by industries. As may be observed in this study, the appraisal done by industrialbased supervisors on gas welding skills possessed by fabrication and welding students substantiate the claim of Prosser's environmental habit theory noting that vocational education will be efficient in proportion as the environment in which the learner is trained is a replica of the environment in which he must subsequently work.

Distinctively, the findings of this study deviated from previous research findings on TVET students' employability skills. For instance, the study of Rasul, Rauf, and Mansor, (2013) revealed that school graduates in Malaysia are not well prepared for the world showing mismatch between the skills acquired in schools and that needed in the world of work. Buttressing this fact, the study of Hanapi, Nordin, and Rus ((2014) also identified lack of employability skills as one of the greatest challenges facing a large number of Malaysian graduates. In another study carried out by Mishra (2014), it was discovered that half of Indian graduates lack requisite employability skills needed by industries.

Consequently, the study of Olakotan (2015) on assessment of employability skills possessed by prospective graduates of technical colleges in mechanical engineering craft practice in Lagos State, Nigeria revealed gross inadequacies between the employability skills possessed by the students and the skills required to secure jobs. Earlier findings of a study conducted by Idris and Rajuddin (2012) also indicated the need for TVET institutions in Nigeria to focus and 
equip the students with employability skills. However, this study as substantiated by its findings upheld fabrication and welding students' employability skills as relevant for employment in the world of work.

\section{CONCLUSIONS AND RECOMMENDATIONS}

This study has shown relative difference among the various studies on TVET students' employability skills. Studies on different trades in TVET institutions revealed that the students lacked the needed skills to function effectively in the world of work. However, this study distinctly revealed that fabrication and welding students in technical colleges in Ogun State possessed sheet metalwork skills and gas welding skills in which this study was delimited to. This position was reiterated in the study as the industrial-based supervisors who have direct contact with the students during industrial attachment affirmed it.

Based on the findings of this study, the following recommendations were suggested: a) Adequate supervision and monitoring of TVET institution's students on industrial attachment should be ensured by TVET institution's administrators; b) Industrial-based supervisors should be objective in discharging their duties during students' industrial attachment period; c) TVET institutions should ensure that students undergo their industrial attachment in related and allied industries; and d) TVET institution's administrators should ensure continued cooperation between TVET institutions and industries.

\section{REFERENCES}

Anangisye, W. A. L. (2008). Developing quality teacher professionals: A reflective inquiry on the practices and challenges in Tanzania. AfricaAsia University Dialogue for Education, CICE Series, 137-154

Dasmani, A. (2011). Challenges facing technical institute graduates in practical skills acquisition in the Upper East Region of Ghana. Asia Pacific Journal of Education (APJCE), 12(2), 67-77.

Ekpenyong, L. E. (2011). Foundation of technical and vocation education: Evolution and practice $3^{\text {rd }}$ ed. Benin City: Supreme Idea Publisher International Ltd.

Federal Government of Nigeria. (2007). Standards and criteria for institutional and programme accreditation in technical colleges and similar technical institutes in Nigeria. Kaduna: NBTE.

Federal Republic of Nigeria. (2013). National policy on education (revised) Lagos: NERDC

Gall, M. D., Gall, J. P., \& Borg, W. R. (2007). Educational research: An introduction. (Eighth Edition). Boston, New York: Pearson Education Inc.

Hanapi, Z., Nordin, M. S., \& Rus, R. C. (2014). Unemployment problem among graduates of technical field: Competencies of the graduates and quality of the education. Sains Humanika, 2(2), 53-57.
Idris, A. \& Rajuddin, M. R. (2012). An assessment of employability skills among technical and vocational education students in Nigeria. Archives Des Science 65(7), 392-400.

Islam, R., \& Mia, A. (2007)). The role of education for rural population transformation in Bangladesh. Asia-Pacific Journal of Cooperative Education, 8(1), 1-21.

Lemo, O. O. \& Olakotan, O.O.(2016). Strategies for enhancing the functionality of metalwork workshops in technical and vocational education institutions in Nigeria. Nigeria Journal of Education, Health and Technology Research. NJEHETR, 8(1): 111-119.

Mishra, A. (2014, 07 February). Growing mismatch between graduates skills market needs. University World News. Retrieved from http://www.universityworldnews.com/article.php? story $=20140204171742828$

Muhammad Y., Soetyono, I. \& Sunardi, K. (2017). Technical skills and employability skills of vocational high school students in Indonesia. Journal of Scientific Research and Studies, 4(6), 148-155.

National Board for Technical Education (2008). Curriculum for Technical Colleges. Kaduna: NBTE Press

Olakotan, O. O. (2015). Assessment of employability skills possessed by prospective graduates of mechanical engineering craft practice in technical colleges in Lagos State. (Unpublished M.Ed Thesis). University of Benin, Benin City.

Rasul, M. S., Rauf, R, A. A., \& Mansor, A. N. (2013). Employability skills indicator as perceived by manufacturing employers. Asian Social Science, 9(8), 42-46.

Rasul, M. S., Ismail, M. Y., Ismail, N., Rajuddin, M. R., \& Rauf, R. A. A. (2010). Development of employability skills assessment tool for manufacturing industry. Jurnal Mekanikal, 30(1), 48-61.

Sience, Technology Engineering and Mathematics Network STEMNET (2014). Employability skills. Retrieved from www.exeter.ac.uk/ambassadors/hestem/resorce S.

Woyo, E. (2013). Challenges facing technical and vocational education and training institutions in producing competent graduates in Zimbabwe. Open Journal of Education, 1(7), 182-189.

Yisa, M. A., \& Olakotan, O. O. (2017). Facilities for effective skill acquisition in welding and fabrication engineering craft practice. Journal of Industrial Education and Training JIET, 4(1), 2228. 